\title{
Smart Grid System to Monitor \& Control Renewable Energy Source based on WoT
}

\author{
*Mr. Adinath S. Satpute \\ ${ }^{1}$ PG Student, Dept. of E\&Tc, SPCOE, Otur (Junnar), \\ Maharashtra, India.
}

\author{
Prof. /Dr. G. U Kharat \\ ${ }^{2}$ Principal, Dept. of E\&Tc, SPCOE, Otur (Junnar), \\ Maharashtra, India.
}

\author{
Prof. R. S Bansode ${ }^{3}$ \\ ${ }^{3} \mathrm{PG}$ Co-ordinator, Dept. of E\&Tc, SPCOE, \\ Otur (Junnar), Maharashtra, India.
}

\begin{abstract}
This article gives special describe about Basic Electric \& smart grid system of renewable energy source based on WoT where include different methodology, its basic working System \& Specification as well Control panel GUI based for easily access and strategy which appeal the application of advance technique in digital technology and information management practices and in appropriate base modernization electrical delivery infrastructure. PV cell mainly used in this system include generation, storage, monitor as well billing by use of a Web of things. This technology is a very effective and increase the extreme efficiency toward quality. Smart grid is increase participation globally towards customer to make them a co part of this system.
\end{abstract}

Keywords- Electric Grid, Smart grid, WoT, GUI Panel for Manage \& Control power, Modernization of electricity.

\section{INTRODUCTION OF ELECTERIC AND SMART GRID}

An electric grid is a one of synchronized power providers as well consumers that are connected by transmits and distribute lines and operated by not only one but also operate more control centers. When we talk about the power "Grid," they're referring to the transmission system for electricity. The electricity grid is a complex and incredibly important system, and one of the most impressive engineering feats of the modern era. Power generated at a variety of facilities and also fed towards end users, often over long distances. It provides electricity to a Commercial buildings, industrial Sector, High-Schools, Agricultural \& homes. And it does so every minute of every day, year-round.

A smart grid system uses it's improve because of its flexibility and Reliable to use (both economic and energy efficient) of the electric system from large generation through the delivery systems to Customers/ Consumers and a growing number of distributed generate, \& Storage resources. Networks that are transforming our economy in other Platforms are also being applied to applications for dynamic optimization of electric system operations, maintenance and planning. Resources and services that were separately managed are now being integrated and rebounded as we address traditional problems in new ways adapt the system to tackle new challenges and discover new benefits that have transformational potential.

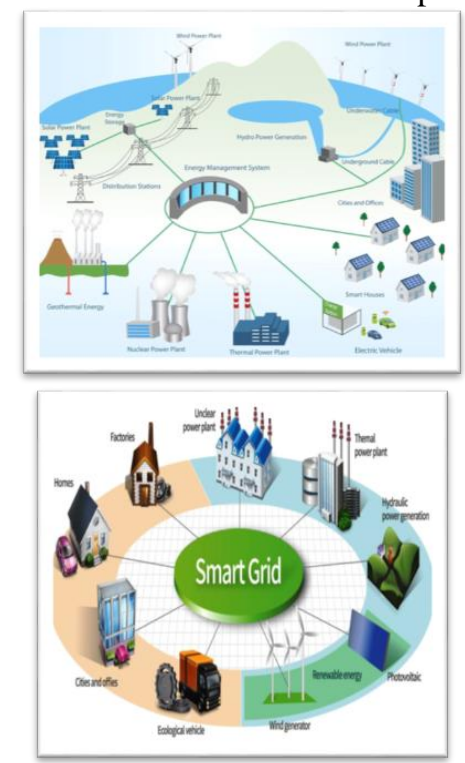

Fig.1 Concept of Basic Electric \& Smart Grid

The innovative idea of this is a variable price profile given to the customer day ahead before the delivery by a retailer. This outline is considered fixed after transmission to the customer and, as such, the customer can rely on it. The actual price profile will look in variant way for each day, reflecting era of market Conditions that vary from day to day. These method of variations will likely further increase with expanding generation from fluctuating sources like wind power and photovoltaic cell. Generally, this concept allows for integration of loads as well as of generation unit at the client site as it is up to the client which devices are allowed to be managed according to the variable tariff. To enable in-home energy management, a suitable domestic system is required together with an auto home management device coupled to a smart meter.

\section{CONCEPT OF WEB OF THINGS (WOT)}

New Power Grid in today's platform is Smart Grid, which is highly integrated with advanced sensor measurement technology, information and communication technology, analysis of the decision-making technology, automatic 
control technology, and energy power technology and grid infrastructures. Traditional grid Compare with smart grid has been improved distinctly in the optimization of power control, the flexibility of grid structure, optimizing the allocation of resources, and improving the power quality of services. Smart grid has so many Feature including strong, self-healing, compatibility, economy, integration and optimization and so forth. Web of Things, namely "the Internet in which the things connected to each other", is the extension and expansion of Internet-based network. On based of agreed protocols, with WOT key technologies: RF identification technology, sensor technology, smart technology and nanotechnology, the communication information can be exchanged, and the intelligent recognition, positioning, tracking, monitoring and management can be achieved.

\section{IMPLEMENTATION AND METHOD'S HELP SUPPORT}

\begin{tabular}{|c|c|c|}
\hline$\overline{1}$ & $\begin{array}{l}\text { Integrating Web-Enabled } \\
\text { Energy -Aware Smart Homes } \\
\text { to the Smart Grid. }\end{array}$ & $\begin{array}{l}\text { In this, we investigate the possibilities created when energy- } \\
\text { Aware smart homes communicate in near real-time with the } \\
\text { smart grid and we propose architecture for their flexible } \\
\text { integration to the grid, through the Web. A proof of concept } \\
\text { deployment is performed and general security agpects are } \\
\text { discussed.[14] }\end{array}$ \\
\hline 2 & $\begin{array}{l}\text { Web of Things for Energy } \\
\text { Management System use of } \\
\text { Smart Grid-Connected } \\
\text { Home. }\end{array}$ & $\begin{array}{l}\text { This paper considers a case study of a gmart grid-connected } \\
\text { home in Australia that has solar photo- voltaic panels for } \\
\text { distributed electricity generation and batteries for local } \\
\text { energy storage. With a focus on Web of Things (WoT), this } \\
\text { paper explores a strategy to facilitate management of } \\
\text { electrical energy in the context of the emerging smart gid } \\
\text { ideas that are consistent with sutainability practices.[3] }\end{array}$ \\
\hline 3 & $\begin{array}{l}\text { Smart Home Area Networks } \\
\text { Protocols within the Smart } \\
\text { Grid Context }\end{array}$ & $\begin{array}{l}\text { The paper presents the most ufilized HANs wired and } \\
\text { wireless communication protocols and discusses their } \\
\text { characteristics, advantages and disadrantages.[11] }\end{array}$ \\
\hline 4 & $\begin{array}{l}\text { A Survey of Energy } \\
\text { Harvesting Technology for } \\
\text { Wireless sensor Network }\end{array}$ & System \\
\hline 5 & $\begin{array}{l}\text { Smart solar photovoltaic } \\
\text { remote monitoring and } \\
\text { Control unit(An IoT Based) }\end{array}$ & $\begin{array}{l}\text { Use of IoT supervising solar photovoltaic power generation } \\
\text { can greatly enhance the performance of monitoring and } \\
\text { maintains of plant. }\end{array}$ \\
\hline 6 & Solar power monitor use IoT & $\begin{array}{l}\text { Include Preventive Maintenance, fault detection of the plant in } \\
\text { addition to real time monitoring }\end{array}$ \\
\hline 7 & $\begin{array}{l}\text { Smart Grid system to monitor } \\
\text { and Control Renewable } \\
\text { Energy Sources use WoT }\end{array}$ & $\begin{array}{l}\text { Power generation, Storage, Power monitor billing and Control } \\
\text { managing by using WoT }\end{array}$ \\
\hline
\end{tabular}

\section{METHODOLOGY}

The proposed smart grid system has Contains of energy sources mainly non renewable Energy Sources that leave a significant carbon emission footprint on the surrounding environment and the second energy sources that we used which comprised number of Renewable energy sources that were echo friendly here the main task achieved is to maximize the utilization of the latter. But the overall Energy Source which is used is taken by the end user of the services that are provided by the implemented Web of Things architecture. In the proposed system the Energy sources are connected to individual digital energy meters of industrial standard having for the purpose. Which are derived from each of these energy meters by means of RS 485(wireless connections). Which is controlled by Internet enabled embedded devices which are in Continuous Constant communication with the meters. The meters data is periodically updated into a server. The server provides the web services that make up the web of thing on top of these embedded system devices. The main server provides services which include display on meter for grab the most adequate information, current working status of load, scheduling of the power sources for each individual from handling setup area and remote location control over the energy sources by switching the source controllers by means of the embedded devices.

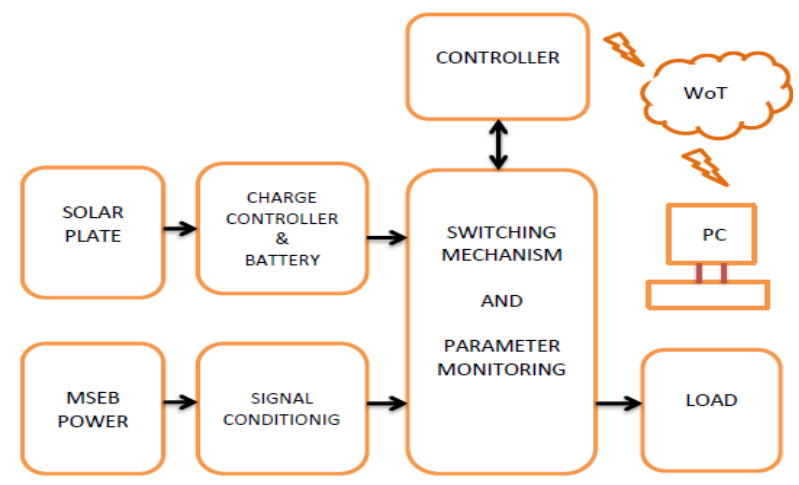

Fig.2 Block Diagram of Smart Grid System Using WoT

User can access services from any computer link to the Internet in this system these source changers are controlled by embedded devices. This embedded devices stand by for the instruction from the server which is moreover instructed by the true user to switch the energy sources. If the users are provided with a cost -effective process to configure the power supply of their homes as per provide or given requirement, the use of generated renewable energy can be maximized or it's distribute to required further Process. This would eventually put an impact on the total carbon emissions due to the creation process of power from non-renewable energy sources. The Web of Things comprise of a number of Internet enabled Embedded devices which furnish such an interface to the user by means of Web services. The end user can access this through a web browser of any computer with an Internet connection.

Only a Valid Customer needs a username and password to gain access to these services from any computer connected to the Internet. Sources availability is useful may at default Condition it may switch over soon. These source changers are controlled by embedded devices, such devices stand the instruction from the server which is furthermore instructed by the authenticated user to switch the energy sources. 


\section{SYSTEM SPECIFICATION FOR BATTERY BACK UP\& CURRENT RATING OF SOLAR}

\begin{tabular}{|c|c|}
\hline \multicolumn{2}{|c|}{$\begin{array}{l}\text { Needs Load backup time and Power Available/Drawn and Available } \\
\text { Battery i/p Voltage }\end{array}$} \\
\hline Calculate Battery Back up & $\begin{array}{l}\text { Required output Load and Load Back up } \\
\text { and Current can be calculate }\end{array}$ \\
\hline $\begin{array}{l}\text { Needs to find Current of } \\
\text { Solar Plate and Power }\end{array}$ & $\begin{array}{l}\text { Available Current and Battery Charging } \\
\text { Hours }\end{array}$ \\
\hline \multicolumn{2}{|c|}{$\begin{array}{l}\text { Formulas: 1. Battery backup=o/p Load *Load Back up } \\
\text { 2. Current=Battery backup/Input } \\
\text { *To calculate solar plate design, Current of System \& Battery } \\
\text { Charging Hours (For Find Current of Solar Plate) } \\
\text { 3. Power=Current *Voltage } \\
\text { So, Solar Specification is } 144 \mathrm{~W}, 12 \mathrm{~A}, 12 \mathrm{~V} \text {. }\end{array}$} \\
\hline
\end{tabular}

\section{RESULT DISPLAY \& STATUS}

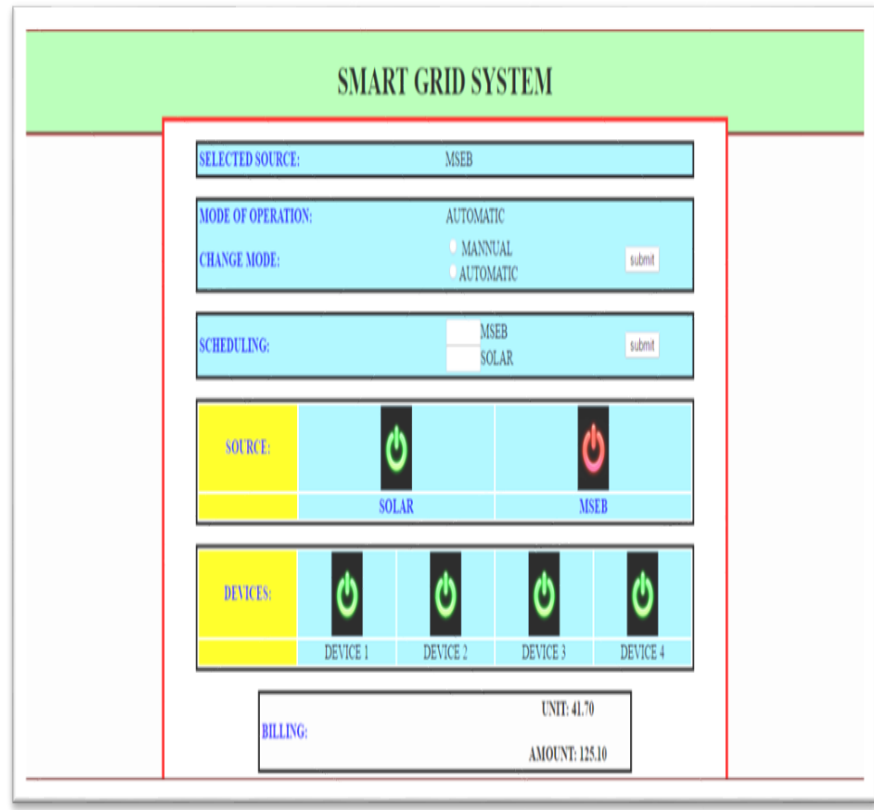

(Web Page Screen) Web page provide controlling status through Auto/Manual.

\begin{tabular}{|c|c|c|c|}
\hline \multicolumn{4}{|c|}{$\begin{array}{l}\text { Below Table shows Connected load according to given reference value } \\
\text { so system will gets run automatically. } \\
\text { (Condition according user define reference to light drops below its may } \\
20 \%, 30 \%, 40 \% \text { so device will run automatically ) }\end{array}$} \\
\hline Illumination & $\begin{array}{l}\text { Ref. } \\
\text { Transducer } \\
\text { Range }\end{array}$ & $\begin{array}{l}\text { Display } \\
\text { Value } \\
\text { In } \%\end{array}$ & Status \\
\hline Dark & 2.0 to $3.0 \mathrm{~V}$ & 20 to $30 \%$ & $\mathrm{ON}$ \\
\hline Dim & 0.8 to $3.0 \mathrm{~V}$ & 40 to $80 \%$ & OFF \\
\hline Moderate & 0 to $7 \mathrm{~V}$ & 85 to $95 \%$ & OFF \\
\hline
\end{tabular}

\section{CONCLUSION}

Access Web page with highly reliable GUI System uses maximum solar energy and minimum MSEB and provides billing only for MSEB not for solar. Its manipulation is in Auto mode. It's Very effective to use of solar energy and hence reduces carbon emission in eco system for user friendly.

\section{REFRANCES}

[1] Yong Ding Christian Decker, Member, IEEE, Iana Vassileva, Fredrik Wallin, Member, IEEE, and Michael Beigl, Member," A Smart Energy System: Distributed Resource Management, Control and Optimization" Vol.12, No.2, February 2014, pp. 940 946.

[2] A smarter grid with the Internet of Things "Texas Instrument, October 2013

[3] Jayavardhana Gubbi, Rajkumar Buyya, Slaven Marusic, Marimuthu Palaniswamia "Internet of Things (IoT): A Vision, Architectural Elements, and Future Directions" Journal of Computer and Communications, 2015, 3, 164-173.

[4] Cristina Alcaraz, Pablo Najera, Javier Lopez, and Rodrigo Roman*, Wireless Sensor Networks and the Internet of Things: Do We Need a Complete Integration? ," ISSN 1424-8220, 2015.

[5] Reji Kumar Pillai President India Smart Grid Forum (ISGF) "Smart Grids in India Vision, Roadmap \& Achievements"

[6] Liu Hua1, Zhang Junguo, Lin Fantao," Internet of Things Technology and its Applications in Smart Grid" TELKOMNIKA Indonesian Journal of Electrical Engineering Vol.12, No.2, February 2014, pp. $940 \sim 946$.

[7] Melike Erol-Kantarci, Member, IEEE, and Hussein $T$ Mouftah," Energy-Efficient Information and Communication Infrastructures in the Smart Grid: A Survey on Interactions and Open Issues", IEEE Communication Surveys \& Tutorials, Vol. 17, No. 1, First Quarter 2015

[8] Sita Ramakrishnan,Subramania Ramakrishnan," WoT (Web of Things) for Energy Management in a Smart Grid-Connected Home", Issues in Informing Science and Information Technology Volume 10, 2013.

[9] Bikash Narayan Panda, Bhawani Shankar Pattnaik, Saswat Mohanty, "Implementation of a Web of Things based Smart Grid to remotely monitor and control Renewable Energy Sources" 2014 IEEE Students' Conference on Electrical, Electronics and Computer Science.

[10] Mahesh Hiremth, Prof: Manoranjan Kumar; "INTERNET OF THINGS FOR ENERGY MANAGEMENT IN THE HOME POWER SUPPLY", International Journal of Research In Science \& Engineering e-ISSN: 2394-8299 Volume: Special Issue: 2 pISSN: 2394-82802007. 